ПРОФЕСІЙНА ПІДГОТОВКА МОЛОДІ УКРАЇНСЬКОЇ ДІАСПОРИ

В УКРАЇНСЬКОМУ СОЦІОЛОГІЧНОМУ ІНСТИТУТІ (УКРАЇНСЬКОМУ ІНСТИТУТІ ГРОМАДОЗНАВСТВА)

\title{
PROFESSIONAL PREPARATION FOR THE YOUNG PEOPLE OF UKRAINIAN DIASPORY IN THE UKRAINIAN SOCIOLOGICAL INSTITUTE (UKRAINIAN INSTITUTE OF CITIZENSHIP)
}

у статmі розкрито перебіг зародження, творення, трансорормації, відновлення та припинення діяльності Українського соціологічного інституту (УСІ) (Українського інституту громадознавства (УІГ) та Українського робітничого університету як його структурного підрозділу в міжвоєнну добу. Проаналізовано етапи орункціонування (під керівниитвом М. Грушевського та М. Шаповала) та всебічно охарактеризовано профресійну підготовку молоді у цих інституціях.

Спираючись на першоджерела та періодику держав потенційного поселення українцівемігрантів, наукові розвідки вчених України та української діаспори, з'ясовано зміст діяльності Українського соціологічного інституту (Українського інституту громадознавства), простежено його трансфрормацію від наукової до науково-практично установи. Розкрито роль визначних персоналій у розгортанні їі активної праці (М. Грушевський, С. Русова, Л. Білецький, О. Ейхельман, І. Шовгенів, Н. Григоріїв, М. Шаповал, С. Шелухін, В. Петрів, В. Доманицький, $€$. Іваненко, М. Мандрика, А. Марголін, С. Гольдельман, А. Животко, Л. Кобилянський, Ф. Швець, В. Січинський, С. Васьківський та ін.). Окреслено просвітницько-виховний контекст фуункціонування Українського соціологічного інституту (Українського інституту громадознавства) та Українського робіт ничого університету, що творили, поруч з іншими академічними установами, український культурно-освітній простір Чехо-Словацької Республіки у 1920-х рр. - 1930-х рр.

Акцентовано на унікальності Українського робітничого університету як дочірньоі установи УІГ (УСІ) і першого українського освітнього закладу з дистанційною фрормою навчання, ролі у справі поширення серед світового українства національної освіти, професійної підготовки та патріотичного виховання. Наголошено на можливості використання цього досвіду в сучасній освітній практиці, зважаючи на новітні хвилі української еміграції та соціально-політичні світові процеси.

Ключові слова: еміграція, діаспора, Український сочіологічний інститут (Український інститут громадознавства), Український робітничий університет, форми, методи навчання, дистанційна освіта.

The article describes the course of origin, creation, transformation, restoration and termination of the activities of the Ukrainian Sociological Institute (USI) (Ukrainian Institute of Civic Studies (UICS) and the Ukrainian Labor University as its structural unit in the interwar period. The stages of functioning (under the guidance of M. Hrushevsky and $M$. Shapoval), and fully described the training of youth in these institutions.

Relying on the source and periodicals of the potential settlement of Ukrainian emigrants, the scientific researches of scientists of Ukraine and the Ukrainian diaspora, the content of the activities of the Ukrainian Sociological Institute (Ukrainian Institute of Civic Studies) was found, its transformation from the scientific to the scientific and practical institution was traced. The role of outstanding personalities in the development of her active work (M. Hrushevsky, S. Rusova, L. Biletsky, O. Eehelman, I. Shovgenov, N. Grigoriev, M. Shapoval, S. Shelukhin, V. Petrov, V. Domanytsky, Y. Ivanenko, M. Mandrika, A. Margolin, S. Goldelman, A. Zhivotko, L. Kobilyansky, F. Svets, V. Sichinsky, S. Vaskivsky and others). The educational and educational context of the functioning of the Ukrainian Institute of Community Studies (Ukrainian Institute of Civic Studies) and the Ukrainian Workers' University, which, along with other academic institutions, created the Ukrainian cultural and educational space of the Czechoslovak Republic in the 1920's and 1930's.

The emphasis is on the uniqueness of the Ukrainian Labor University as a subsidiary of UICS and the first Ukrainian educational institution with a distance learning form, and the role of national education, professional training and patriotic education among the world's Ukrainians. The possibility of using this experience in modern educational practice is emphasized, taking into account the latest waves of Ukrainian emigration and socio-political world processes.

Key words: emigration, diaspora, Ukrainian sociological institute (Ukrainian Institute of Civic Studies), Ukrainian Labor University, forms, teaching methods, distance education.
Постановка проблеми у загальному вигляді. Сучасні державотворчі процеси і виклики, пов'язані 3 ними, спонукають до вивчення та переосмислення досвіду поколінь наших співвітчизників, які з різних причин змушені були залишити рідну землю. У цьому контексті видається актуальним фрункціонування соціологічних студій українського зарубіжжя та їх найвідоміших представників, адже дослідження процесів інституціоналізації української соціології та суміжних 3 нею наук, зокрема соціальної педагогіки, які відбувалися в міжвоєнний період, в умовах браку політичної і наукової легітимностей, відсутності чи нестачі фрінансування, становить значну наукову цінність. Окрім цього, сучасний етап фрормування нових зовнішньополітичних та економічних векторів суспільства, тенденція переходу від індустріальних до науково-інорормаційних технологій, реалізація основних положень чинних нормативно-правових документів у сорері вищої освіти і науки України 
спричиняють значні зміни в її системі та диктують принципово нові шляхи розвитку вищої школи і фрормування особистості фрахівців, спроможних іти в ногу з часом. Через те питання освіти впродовж життя, профресійна підготовка молоді в академічних і профресійно орієнтованих закладах освіти є відгуком на перелічені вище стратегічні напрями сучасності, а їх актуальність є безсумнівною.

Аналіз останніх досліджень і публікацій. До проблеми, винесеної в заголовок публікації, зверталася І. Матяш, яка здійснила періодизацію роботи Українського соціологічного інституту (далі - УСІ), заснованого М. Грушевським, виокремивши женевський, празький та віденський етапи в роботі цієї установи [11]. Д. Судин наголосив на поєднанні наукової праці М. Грушевського як творця УСІ з громадсько-політичною метою, що дає змогу осягнути логіку його дій за кордоном, оскільки першочерговими завданнями УСІ були, на його думку, політичні, а вся наукова діяльність задумувалася як основа для переведення політичної на якісно новий рівень [16]. О. Сухобокова розкрила роль Українського робітничого університету як інституції, що творила, поруч з іншими академічними установами, українське культурноосвітнє середовище в Чехо-Словацькій Республіці у 20-х рр. XX ст. [17]. В. Трощинський зосередився на історичних пріоритетах організації й наукової праці УСІ Чехо-Словацького періоду [19]. У працях О. Джус УСІ (УІГ) розглядається як тло розгортання діяльності видатного педагога і громадської діячки Cофрії Русової [3] або ж фррагментарно в контексті окремих тем [2; 4]. У виданнях довідкового характеру знаходимо короткі інформаційні довідки про Український соціологічний інститут (Відень, Прага) [12; 22].

Виділення невирішених раніше частин загальної проблеми. Нагальна об'єктивна потреба україноцентричного фрокусування на історії національної педагогіки в контексті європейських і світових освітніх традицій, аналіз місця і ролі інституцій 3 підготовки національно свідомих громадян-фрахівців для потреб економіки незалежної України вимагають більш глибокого вивчення змісту діяльності Українського соціологічного інституту (Українського інституту громадознавства) та його дочірньої установи Українського робітничого університету.

Мета статті. Відповідно, метою статті $\epsilon$ з'ясування сутності професійної підготовки молоді української діаспори в Українському соціологічному інституті (Українському інституті громадознавства) й Українському робітничому університеті (його структурному підрозділі) як інституцій, що були покликана сорормувати генерацію національної інтелігенції, політичної еліти, свідомих, освічених громадян та фрахівців-професіоналів робітничої еміграційної спільноти.
Виклад основного матеріалу. Український соціологічний інститут був заснований Михайлом Грушевським спільно з членами Української партії соціалістів-революціонерів 1919 року у Відні. Наукова робота УСІ на початках своєї діяльності передбачала відстежування результатів світових соціологічних досліджень та налагодження контактів із провідними європейськими науковцями. Разом із тим у наступні періоди фрункціонування УСІ, до співпраці з яким М. Грушевський долучив В. Липинського, В. Старосольського та ін., головною метою діяльності інституту стало об'єднання українського суспільства, поширення інформації про соціальне життя українців серед європейської спільноти. Тобто, окрім наукової, УСІ переслідував і культурно-просвітницьку ціль.

Упродовж 1921-1922 рр. співробітники Українського соціологічного інституту займалися переважно видавничою та лекторською діяльністю. До 1921 р. побачили світ праці, присвячені різним аспектам минулого й сучасного життя України, зокрема: «Початки громадянства» М. Грушевського, «Замітки і матеріали до історії української революції» П. Христюка, «Галичина в 1918-1920» М. Лозинського, «Теорія нації» В. Старосольського, «3 починів укр. соц. руху. М. Драгоманов женевський гурток». Для українців-емігрантів були організовані безкоштовні курси із суспільних наук, на яких розглядалися питання соціології, політології, історії тощо [2]. Однак варто визнати, що як науковий заклад віденський інститут існував номінально і то лише до 1924 р., коли М. Грушевський повернувся в УРСР.

Справу М. Грушевського продовжив М. Шаповал - політичний і громадський діяч, публіцист, соціолог, поет. Діяльний соціаліст за переконаннями, він розгорнув активну роботу в еміграції як голова Українського Громадського Комітету, ставши ініціатором творення низки українських високих шкіл у столиці Чехо-Словацької республіки. Він таким чином означив появу в Празі Українського інституту громадознавства, з 1929 року Українського соціологічного інституту: «утворення науки соціології на укр.[аїнському] ґрунті, підготовки сил, вивчення України і проблем світової політики, економіки, права, культури...» [8, с. 21].

I М. Грушевський, і М. Шаповал переслідували стратегічну мету: формування соціально активної, громадянсько і політично соціалізованої особистості як неодмінної умови становлення майбутньої незалежної України. Мотиви, якими керувався Микита Шаповал, виступаючи ініціатором створення в Празі приватної української науководослідної установи соціологічного профрілю, найкраще розкривають такі слова вченого «Відповідь про реальну програму визволення нам дасть або соціологія, або <..> ніхто й ніщо. Мусимо через те поставити перед усіма, що чекають відповіді, 
поставити ясно: замість чекати - треба шукати відповіді і то там, де вона може бути: в науці про суспільство, в - соціології» [21, с. 41].

Проект інституту був розроблений М. Шаповалом у червні 1924 р. Наприкінці того ж року вдалося здійснити перші практичні кроки щодо його організаційного оформлення. Але фрактична діяльність УІГ розпочалася тільки 1 листопада 1925 р. В Українському інституті громадознавства діяли такі відділи: соціології і політики, народознавства, економіки й техніки та відділ правознавства. Кожен із відділів мав семінари і кабінети для поглибленого вивчення окремих проблем (соціології, народного господарства, педагогіки тощо). Директором Українського інституту громадознавства став М. Шаповал (у 1929 р. на деякий час - Л. Білецький), котрий водночас керував відділом соціології й політики. Відділ народознавства, в якому педагогічний семінар очолювала С. Русова, працював під керівництвом Н. Григоріїва, згодом - Л. Білецького; економіки й техніки - В. Коваля, С. Гольдельмана, О. Мицюка; правознавства - С. Шелухина $[3$, c. 22].

Науковою радою (згодом - Колегією) інституту керував О. Ейхельман. Головною фрормою діяльності інституту були доповіді в семінарах та на засіданнях, а також численні виклади його членів як у Чехо-Словаччині, так і в інших країнах Європи й Америки (наприклад, лише один М. Шаповал упродовж своєї подорожі до США в 1930 р. зробив понад 100 доповідей на різні соціологічні теми).

Найпродуктивніший період орункціонування інституту припадає на початок 1930-х років. У цей час вийшло шість випусків (три книги) збірника «Суспільство» - періодичного наукового органу, в якому публікували свої праці українські й зарубіжні вчені-соціологи. Водночас понад 50 творів побачили світ як окремі видання, серед них - «Засади соціальної педагогіки» С. Русової [23, арк. 56]. Наприкінці 1925 р. відділ народознавства приступив до видання збірника «Україна» фрранцузькою мовою $з$ метою «ознайомити Європу з Україною в минулому й сучасному» [24, арк. 3]. На жаль, відомостей про його появу нами не виявлено. У 1930 р. вийшов збірник Українського соціологічного інституту «Народознавство», серед авторів публікацій якого були Л. Білецький, Н. Григоріїв, А. Животко, Г. Омельченко, М. Омельченко, С. Русова, М. Шаповал та ін. Навіть цей неповний перелік видань вказує на активну наукову діяльність працівників соціологічного інституту та їхню місію: дослідження українського суспільства на глибоко науковій основі.

У 1927 і в 1930 рр. М. Шаповал перебував у США й Канаді, де виступав 3 лекціями перед українськими емігрантами. Ця поїздка стала поштовхом до заснування при Українському соціологічному інституті заочного Українського робітничого уні- верситету за прикладом американського досвіду «листовного» (кореспонденційного) навчання молоді.

Поява Українського робітничого університету (далі - УРУ) як структурного підрозділу УІг та закладу професійної підготовки робітничої молоді в українській діаспорі стало практичним внеском щодо поширення освіти серед української еміграції. Адже переважну ії̈ більшість становили «70\% неграмотні, темні, забиті люди <..> ще не організовані, бо не знають, як це зробити» [5, с. 1-2]. Микита Шаповал убачав історичну роль у просвіті українства: «Лишень наукова організація думки селян і робітників зможе привести до визволення Україну <...> 40 мільйонів українців, озброєні наукою, зроблять те, чого не зможуть зробити гармати» [9, с. 119].

Реалізувати амбітне завдання охопити навчанням найширше коло українських робітників у всьому світі стало можливим лише шляхом запровадження дистанційної фрорми навчання. Можна сміливо стверджувати, що цей заклад став предтечею української дистанційної освіти.

Зауважимо, що створення вищого заочного навчального закладу для масової освіти було предметом обговорення в Українському громадському комітеті (навіть було розроблено проект організації Селянського університету на базі профресійних шкіл Української Селянської Спілки), а згодом - в Українському Комітеті та Інституті громадознавства. Проте через брак коштів цю ідею впродовж тривалого часу не вдавалося реалізувати. Зрештою, Головний Комітет Закордонної Організації української партії соціалістів-революціонерів відкинув спроби відкрити університет за допомогою меценатів, уважаючи, що справа визволення трудового народу має бути в його власних руках [17, с. 321].

Ідея була підтримана українськими емігрантами та їхніми організаціями, зокрема такими впливовими, як «Оборона України» та Український робітничий союз. Матеріальна підтримка була надзвичайно важливою, особливо з огляду на те, що чехословацький уряд змінив політику щодо української еміграції з 1927 р. За результатами дослідження О. Сухобокової, під керівництвом М. Шаповала 18 квітня 1927 р. у США у Скрентоні було створено перший Комітет допомоги Українському робітничому університету. Згодом аналогічні комітети виникли у багатьох американських містах з українськими громадами (Детройт, Чикаго, Філадельфрія, Рочестер та ін.), а також в Європі Льєж (Бельгія), Париж (Франція), Львів (Польща), Яблонне (ЧСР) і т.д. Спонсорами, а отже, й фрундаторами університету стали не лише трудові колективи, українські організації та установи з різних країн, а й самі ініціатори створення університету, серед них - М. Шаповал та Н. Григоріїв [17, с. 322]. 
Організаційний комітет Уру було утворено, за одними даними, 30 квітня, за іншими - 1 липня (остання дата $€$ більш ймовірною) 1927 р. у Празі. До його складу увійшли визначні громадські діячі, члени Головного політичного комітету Закордонної організації Української партії соціалістів-революціонерів - М. Шаповал (голова), Н. Григоріїв (заступник), М. Мандрика (секретар), Л. Кобилянський, С. Довгаль, Б. Залевський, К. Станіславський, Л. Клименко, М. Косенко. У стислі терміни (УРУ планувалося відкрити в жовтні 1927 р.) Комітет здійснив потужну організаційну роботу: окрім збору коштів та вирішення господарських проблем, пропаганди закладу, ссрормував лекторсько-викладацький склад, розробив статут університету, детальні програми навчання, провів набір і зарахування студентів [25, арк. 22-22 зв.; 26, арк. 2-7].

Як автономна установа Українського інституту громадознавства УРу розпочав діяльність наприкінці 1927 р. і керувався окремим статутом, затвердженим Кураторією інституту 30 жовтня 1928 р. В УРУ викладали «ліпші фрахові українські сили, що стоять на ґрунті інтересів трудового українського суспільства», відомі українські громадські діячі та вчені: С. Русова, Л. Білецький, О. Ейхельман, І. Шовгенів, Н. Григоріїв, Микита і Микола Шаповали, С. Шелухін, В. Петрів, В. Доманицький, $€$. Іваненко, М. Мандрика, А. Марголін, С. Гольдельман, А. Животко, Л. Кобилянський, Ф. Швець, В. Січинський, С. Васьківський та ін. [28, арк. 12].

Програма Українського робітничого університету заочного навчання передбачала створення фракультету суспільних наук 3 курсами українознавства, суспільствознавства (соціології), сучасної політики.

Були засновані також матуральні курси (спеціальний відділ заочної середньошкільної освіти), на яких планувалося додатково вивчати спеціальні педагогічні дисципліни [1, с. 17-19]. Потреба в них була очевидною, оскільки переважна більшість українських робітників-емігрантів не мала закінченої шкільної освіти. Дистанційна форма навчання дозволяла їм, не відриваючись від праці, продовжити здобувати освіту. Варто наголосити і на психологічному чиннику: зрілі, а часто і поважного віку люди у такий спосіб могли, не соромлячись, вивчати шкільні предмети.

Курс навчання на матуральних курсах передбачав два цикли - програма нижчої реальної школи (4 класи) та вищої реальної школи (останні 5-7-й чи 5-8-й класи). Викладалися загальноосвітні предмети: українська мова, математика, геометрія, фрізика, хімія, природознавство, географрія, історія, іноземна мова тощо. На засвоєння кожного із цих циклів йшло 1-2 роки, тобто всю програму середньої школи можна було опанувати за 2-3 роки [27, арк. 18, 37-39].
Слухачем УРУ міг стати кожний українець, незалежно від віку і країни проживання, який умів читати й писати. Із зрозумілих причин цим правом не могли скористатися громадяни радянської України. Записалося до університету понад 500 осіб (переважно малоосвічені робітники), 3 них близько 70\% перебувало на корінних (західноукраїнських) землях, а решта - в еміграції, майже в усіх країнах світу [12, с. 25]: західноукраїнські землі (Галичина і Волинь) - 36\%; ЧСР - 19\%; Підкарпаття - 18\%; США - 11\%; Канада - 6,5\%; Франція - 5\%; Бессарабія, Буковина, Бельгія, Болгарія, Аргентина, Палестина та інші країни - 4,5\%. Таким чином, більше 50\% студентів мешкало на етнічних українських теренах.

Про ареал студентів УРУ свідчить і кількість та місцезнаходження його представництв у США з відділами у Нью-Йорку (Б. Залевський), Бостоні (А. Капровий), Чикаго (Д. Мойсюк), Детройті («Оборона України»), Скрентоні (А. Батюк); Канаді - Вінніпег (М. Мандрика, «Народний дім»), Торольд (М. Мизинчук), Торонто (С. Милан); Бразилії (А. Корчнівський), Франції (М. Шаповал), Бельгії (І. Завзятий), Польщі (галицька організація на чолі з М. Матчаком і волинська - з А. Огієм) [6; 28, арк. 5-6].

За даними В. Трощинського, на початку 1929 р. в університеті заочно навчалися понад 600 осіб, які походили: з Галичини й Буковини - 36\%, із Закарпаття - 18\%; емігранти з Чехо-Словаччини - 19\%, США - 11\%, Канади - 6,5\%, Франції - 5\%; переселенці з інших країн - 4,5\%. Вік слухачів коливався від 15 до 45 років [19, с. 144]. 62\% з них становили робітники і $14,3 \%$ - селяни. Загалом, $75,2 \%$ становили особи працездатного та найбільш активного віку.

Щодо освітнього рівня абітурієнтів УРу, більшість не мала навіть середньої освіти: вищу освіту мали $0,5 \%$, середню - 12,2\%, вищу початкову $22,6 \%$, початкову - $57,6 \%$ та $7,1 \%$ лише займалися самоосвітою [6, с. 5-6].

Навчання в університеті було організоване шляхом надсилання друкованих навчальних матеріалів (лекцій та комплексу завдань і вправ до них), за змістом, регулярністю друку і висилкою яких уважно стежили досвідчені педагоги та інструктори. Студент вдома, у зручний для нього час самостійно вивчав їх, послуговуючись «живим, хоч і далеким словом вчителя», виконував завдання до кожної теми та відсилав їх на перевірку. У разі виникнення якихось ускладнень він міг звернутися за допомогою чи роз'ясненнями до інструктора. Доки роботу студента перевіряли викладачі (під контролем академічної колегії університету), він, не гаючи час, міг вивчати нову тему, а потім, за потреби, повернутися до попередньої, працюючи над помилками. Така система організації навчального процесу забезпечувала індивідуальний підхід 
до кожного студента, враховуючи його успішність та наявність вільного часу [20, с. 111; 14, с. 11].

Творці УРу наголошували на його головній перевазі: «Не треба робітникові одриватись од праці, ходити на лекції - у нього нема часу, - Робітничий університет сам прийде до нього у хату, як добрий приятель, принесе науку і знання» [27, арк. 42].

Провідними дисциплінами в УРУ, як і передбачалося його програмою, були українознавство, суспільствознавство і «сучасні суспільні справи». Зокрема, викладалися такі дисципліни:

- у відділі українознавства: «Населення України (соціографрія)» (10 лекцій), «Географрія і кліматологія (фрізична і політична)» (7), «Економічна географрія» (7), «Соціально-політична історія України» (15), «Історія відродження України» (2), «Велика революція» (5), «Українське письменство» (10), «Українське мистецтво» (5), «Господарство України» (10); окремими курсами викладалися предмети «Як учити дітей по українськи?» та «Як стати письменним українцем?» (по 5 лекцій);

- у відділі наук про суспільство: «Устрій суспільства (соціальна аналітика)» (7), «Діяльність суспільства (суспільна механіка): господарська (5), культурна (5), політична (5)», «Походження і розвиток суспільства (суспільна генетика)» (7), «Основи політики» (5), «Охорона народного здоров'я» (3), «Основи суспільного виховання» (5), «Суспільний контроль» (5), «Теорія оборони нації» (5), «Історія соціологічних теорій» (10);

у відділі сучасної політики: «Робітнича справа (профрспілковий рух, соціалізм, партії та об'єднання, Інтернаціонал тощо)» (10), «Селянська справа (боротьба селянства за землю і волю, селянські партії, селянство і робітництво)» (5), «Національна справа» (5), «Політика великих держав (імперіалізм)» (5), «Міжнародне господарство» (5), «Більшовицька Росія і Україна (Велика революція)» (10), «Військова справа» (5), «Сусіди України» (5) [25, арк. 23; 27, арк. 49; 29, арк. 1-20].

Зважаючи на зміст програми дисциплін, першочерговим завданням УРУ було підняти загальний освітній рівень та національну свідомість українців, що закладало ґрунт для підвищення їхньої суспільно-політичної активності [10, с. 1].

3 метою вдосконалення навчання УРУ розгорнула власну видавничу діяльність. Оскільки української наукової і навчальної літератури 3 даної проблематики практично не було, а існуюча не відповідала вимогам УРУ, викладачами з кожного предмету спеціально готувалися посібники (як правило, на основі лекцій). Їх друк почався на початку жовтня 1927 р., і вже з кінця місяця до грудня студентам вислали перші 3 них - «Соціограсрія України», «Робітниче питання», «Селянське питання», «Історія України», «Народне господарство України», «Географрія України». Регулярну розсилку лекцій, інструкцій та посібників налагодили з листопада 1927 р. (спочатку по 4-6 лекцій на місяць, а згодом - за індивідуальними можливостями студентів) [17, с. 328].

За період 31 січня 1928 р. по 1 травня 1931 р. було надруковано і надіслано 110 лекційних викладів (що становило 1200 сторінок «густого друку») по 300 примірників кожного [27, арк. 13 зв., 17; 13, с. 7-8], зокрема такі: «Соціографрія України» Л. Безручка, «Історія України» й «Історія українського народу» Н. Григорієва, «Засади української визвольної програми», «Соціологія і політика» та «Земельна справа в Галичині» М. Шаповала, «Національна справа» М. Мандрики, «Звідки походять назви «русини», «Русь», «галичани», «малороси» і «українці» С. Шелухіна, «Народне господарство», «Промисловість України» С. Гольдельмана, «Робітнича справа» Л. Романюка, «Селянська справа» та «Книга і читач» А. Животка, «Військова справа» В. Петрова, «Українська музика» Л. Кобилянського та інші [27, арк. 53; 32, арк. 3]. У 19301931 рр. було введено нові предмети на відділі українознавства та суспільних наук - «Відродження українського народу», «Теорія держави», «Поведінка і світогляд» Н. Григорієва, «Українська етнографія» Л. Білецького, «Світові селянські революційні рухи» А. Животка, «Теорія кооперації» $\mathrm{i}$ «Сучасний стан робітничого руху» С. Довгаля та ін. $[17$, с. 328]. Характерною особливістю лекційних викладів та навчальних посібників, розроблених в УРУ, було те, що вони відповідали вимогам європейської вищої освіти, але викладалися в популярній (хоч і цілком науковій) фрормі, зрозумілою для широкого загалу мовою [30, арк. 15].

За переконанням О. Сухобокової, багато навчальних предметів та курсів були цілком новаторськими за змістом, концептуальними. А це у свою чергу вимагало і високого інтелектуального рівня цих розробок, стимулювало його і таким чином робило неоціненну послугу вітчизняній суспільній науці та гуманітарній освіті, відкриваючи перед ними нову перспективу та піднімаючи їх на рівень передової наукової думки. Можна стверджувати, що завдяки їй було досягнуто справжнього прориву в таких вкрай важливих галузях суспільствознавства, як соціологія, народознавство, культурологія, і то, в порівнянні не лише з «марксизмом», а точніше - догматично-комуністичним вченням, а й зі здобутками багатьох, як вважалося, на той час передових європейських учених і наукових шкіл. Водночас ці розробки варто розглядати у контексті наукового пошуку і роботи Українського соціологічного інституту [17, с. 328-329].

3 грудня 1927 р. почав виходити неперіодичний друкований орган університету - «Вісник Українського Робітничого Університету» за редакцією Микити Шаповала, Никифора Григорієва, Спиридона Довгаля та Аркадія Животка [30, арк. 1-4]. 
Журнал інорормував про справи університету і життя його студентства, українських робітників в Україні та світі. Також він сприяв зв'язку університету зі студентами та абітурієнтами (постійною була рубрика листів від студентів й відповідей на їхні запитання). До травня 1930 р. було видано 7 чисел «Вісника» [31, арк. 4; 7, с. 18].

Варто наголосити, що праця в робітничому університеті проводилась більшістю профресорів і членів адміністрації безоплатно. Як підкреслювала С. Русова - доктор соціолоґії Honoris Causa, дійсний член відділів соціології і політики та народознавства УІГ, викладач (а згодом і член дирекції) УРУ, вони трудилися «з певною свідомістю, що український поневолений народ потребує більш, аніж який другий більш щасливий народ, наукового аналізу сучасних обставин як загальносвітових, так і власного суспільного життя, потребує синтезу <..> способів власного визволення, а також наукового роз'яснення причин, що тримають його в неволі. Він - так мало освічений, потребує науково установленого громадського світогляду і суспільної організованості. Розкинутий по 4 чужих державах вічно в утисках чужих влад, український народ має і громадянство, розбите на безліч ідейних гуртків. Це усе зміцняє безпомічність укр. народу і український Вільний Інститут Громадознавства радо працює, щоб поширити світогляд українського громадянства і правдиво пояснити йому причини його підневільного життя» $[18$, c. 427].

Разом із тим з огляду на припинення як пожертв, так і оплати за лекції (та й загалом політичну ситуацію в Європі, яка спровокувала подальші хвилі української еміграції), дирекція УРУ спочатку скоротила обсяг діяльності, а потім і зовсім перестала видавати і відправляти студентам допоміжні матеріали. А на засіданні соціологічного інституту 9 квітня 1931 р. було ухвалено припинити роботу цієї важливої просвітянської інституції.

Попри це, його роль важко переоцінити, оскільки українці в діаспорі, не маючи власної держави, перебуваючи на різних континентах, незалежно від місця проживання і способу життя, могли здобувати національну освіту. Український робітничий університет як складова частина Українського соціологічного інституту належав до установ, які поклали початок соціологічним дослідам на українському ґрунті, це була інституція, що несла «світло в найменші українські хати...» $[15$, с. 8].

Висновки. Беручи до уваги час, місце та інші об'єктивні й суб'єктивні обставини функціонування Українського інституту громадознавства (Українського соціологічного інституту) та Українського робітничого університету, з певністю можна стверджувати про унікальність цих інституцій, особливо УРУ як першого українського освітнього закладу
3 дистанційною фрормою навчання. Їх організація, звісно, не була позбавлена недоліків, і вони не зреалізували вповні задуми й плани своїх засновників. Разом із тим їх значення було, безсумнівно, великим для справи поширення серед світового українства національної освіти, професійної підготовки робітничої молоді та патріотичного виховання. А цей досвід може бути використаний у сучасній освітній практиці, зважаючи на новітні хвилі української еміграції та соціально-політичні світові процеси.

\section{БІБЛІОГРАФІЧНИЙ СПИСОК:}

1. Вісник українського Робітничого Університету. Прага. 1927. Грудень. 19 с.

2. Джус О. Михайло Грушевський і фрункціонування Українського соціологічного інституту як першого наукового закладу української еміграції. Міжнародна наукова конореренція до 150-ліття М.С.Грушевського : тези доповідей (17 вересня 2016 р., м. Острог) ; Міністерство освіти і науки України ; Національний університет «Острозька академія» ; Українське історичне товариство. Острог : Видавництво Національного університету «Острозька академія», 2016. С. 97-99.

3. Джус О. Творча спадщина Софії Русової періоду еміграції: монографрія. Івано-Франківськ : Плай, 2002. $260 \mathrm{c}$

4. Джус О. Український робітничий університет у Празі - предтеча дистанційної освіти українського зарубіжжя. Інновації в освіті : матеріали Міжнар. наук.-метод. конфр. (Київ, 16-17 жовтня 2012 р.) : тези доповідей. Київ : Київ. нац. торг.-екон. ун-т, 2012. С. 32-34.

5. До українських селян і робітників. Вісник Українського робітничого університету. 1927. Грудень. С. 1-2.

6. Довгаль С. Рік праці Українського Робітничого Університету. Вісник Українського Робітничого Університету. 1928. Червень - серпень. С. 7.

7. Животко А. Українська партія соціалістів - революціонерів і преса (з нагоди 50 років праці УПС-Р). Трудова Україна. 1934. Ч. 12. С. 18.

8. 3 праці Українського Соціологічного Інституту в Празі. Трудова Україна. 1932. Ч. 1. С. 21-23.

9. 3 хроніки Українського Робітничого Університету. Нова Україна. 1928. Ч. 4-6. С. 119.

10. 3 чергових завдань. Вісник Українського Робітничого Університету. 1928. Квітень - травень. С. 1.

11. Матяш І. Український соціологічний інститут М.С. Грушевського: основні напрями та етапи діяльності. Український історик. 2000. Ч. 4. С. 44-56.

12. Наріжний С. Українська еміграція. Культурна праця української еміграції 1919-1939 (матеріали, зібрані С.Наріжним до частини другої). Київ : Видавництво імені Олени Теліги, 1999. 272 с.

13. Перші лекції. Вісник Українського Робітничого Університету. 1927. Грудень. С. 7-8.

14. Проспект курсу позаочної середньої освіти, організованого при Українському Робітничому Університеті. Вісник Українського Робітничого Універcumemy. 1928. Червень - серпень. С. 11. 
15. Святкування «Дня У.Р.У.». Вісник Українського Робітничого Університету. Прага, 1928. Квітень травень. С. 5-9.

16. Судин Д.Ю. Женевський період діяльності Українського соціологічного інституту (серпень 1919 - березень 1920 рр.). Вісник Львівського універcumemy. Серія соціологічна. 2012. Вип. 6. С. 37-50.

17. Сухобокова О. Український робітничий університет у Празі (1927-1931рр.). Проблеми історії України: фракти, судження, пошуки : міжвід. зб. наук. пр. 2007. Вип. 17. С. 320-334.

18. Русова Софія. 3 маловідомого і невідомого ; упоряд. О.Джус, 3. Нагачевська ; автор вступ. статті 3. Нагачевська. Івано-Франківськ : Гостинець, 2006. Ч. 1: Несторка української педагогічної літератури. 456 с.

19. Трощинський В. Український Соціологічний Інститут у Празі: організація і наукова праця (1924-1932 рр.). Українська діаспора. 1992. Ч. 2. C. $138-150$.
20. Хроніка українського Робітничого Університету. Нова Україна. 1927. Ч. 10-11. С. 111.

21. Шаповал М. До питання про організацію українських соціологічних студій. Суспільство. 1925. 4. I-II. C. 24-42.

22. Юренко О Український Соціологічний Інститут у Празі. Політична енциклопедія ; редкол. : Ю. Левенець (голова), Ю. Шаповал (заст. голови) та ін. Київ : Парламентське видавництво, 2011. С. 734.

23. ЦДАВО України. Ф. 3563. Оп. 1. Спр. 77.

24. ЦДАВО України. Ф. 3793. Оп. 1. Спр. 20.

25. ЦДАВО України. Ф. 3793. Оп. 1. Спр. 43.

26. ЦДАВО України. Ф. 3794. Оп. 1. Спр. 1.

27. ЦДАВО України. Ф. 3794. Оп. 1. Спр. 2.

28. ЦДАВО України. Ф. 3794. Оп. 1. Спр. 4.

29. ЦДАВО України. Ф. 3794. Оп. 1. Спр. 7.

30. ЦДАВО України. Ф. 3794. Оп. 1. Спр. 15.

31. ЦДАВО України. Ф. 3794. Оп. 1. Спр. 35. 